\title{
PHYSICAL EDUCATION AND HEALTHY LIFESTYLE
}

\author{
Nenad Živanović1 ${ }^{\text {, Zoran Milošević2 }}$, Veroljub Stanković ${ }^{3}$ \\ Nebojša Ranđelović ${ }^{4}$ and Kristina Pantelić-Babić ${ }^{5}$ \\ ${ }^{1}$ FIEP Europe - President of History of physical education and sport section \\ 2 University of Novi Sad Faculty of Sport and Physical Education, Novi Sad, Serbia \\ ${ }^{3}$ University of Priština, Faculty of Sport and Physical Education, Leposavić, Serbia \\ ${ }^{4}$ University of Niš, Faculty of Sport and Physical Education, Nišs, Serbia \\ ${ }^{5}$ FIEP Europe - Secretary of History of physical education and sport section
}

UDK 796.011:13

\section{SUMMARY}

Physical Culture, as a part of general culture, can be defined as a human activity, which, through its knowledge ABOUT and FOR physical exercise within its areas (physical education, sports and physical recreation), allows the transformation of personality from real to possible. Physical Education, as one of the areas of Physical Culture, istherefore a very important educational link. It is particularly important in anera characterized by fast technological advances and technicalism that is rapidly introducing people to virtual reality. Hence, we emphasize that Physical Education, with its knowledge ABOUT and FOR physical exercise, buildsthe basis for a healthy, active and long life in young people.This is possible due to the fact that Physical Education, based on the Theory of Theoanthropocentrism, sees physical exercise as a beneficial body activity necessary for man and stems from the relationship to a man as a person, not an individual.

The increasingly present virtual reality is in complete harmony with the sedentary culture, increasingly dominant not only in Western civilization. This undoubtedly leads to "active" hypokinesia, the root of many disturbing changes and health problems.

Corresponding author

Nenad Živanović

nenad.zivanovic46@gmail.com 
Anthropological research conducted in Serbia and AP Vojvodina have confirmed that the number of people who regularly engage in physical exercise is decreasing. That is why we point out the importance of Physical Education, which, with its knowledge of how and why to exercise, builds the awareness of the necessity for physical exercise, as well as of the possibility of seeing every physical activity as physical exercise.

Key words: theoanthropocentrism, physical exercise, physical activity

\section{INTRODUCTION}

Physical education as a field of physical culture, potentionally defined as a human activity which in the areas of general knowledge, the knowledge OF physical exercise and the knowledge FOR physical exercise enables a transformation of personality from the real to the feasible within its limits ${ }^{1}$, represents a very important link in education. It is of particular importance at the time characterized by advances in technology and technicism taking man into virtual reality with an increasing power. This is why we highlight the fact that physical education with the knowledge $\mathrm{OF}$ and the knowledge FOR physical exercise provides a solid foundation for a healthy, active and long life. Being such and the only correct one - healthy foundation is feasible because with physical education relying on the theo-anthropocentristic approach physical exercise can be considered as the most beneficial nutrient one may need, which results from the relationship with man as a person and not an individual.

The relationship to man as a person is based on the understanding - that spirituality is a thin line separating them. It is therefore very important what kind of knowledge and on what basis one can acquire. Of course, at present time with predominant Western culture, it is very difficult to build up knowledge on the spiritual value basis. This is because a vacant seat left after abandoned spirituality is now occupied by materiality that is, money. Thus, according to the Western materialistic principles, physical exercise has also become a merchandise for (costly) sale.

Another equally threatening issue is increasing hypokinesia. Reduced physical activity and thus reduced physical exercising results in imbalance and a complete discord between one's spiritual and material values in the given social circumstances. All of this affects not only one's health but also the nation's health.

\footnotetext{
${ }^{1}$ Nenad Živanović et al., The Theory of Physical Culture, Panoptikum, Niš, 2010, p. 18.
} 
Highlighting the fact that there are many various definitions of health, which only proves that the concept of the term itself is very complex, we can recall an early definition of health invented by the World Health Organization (WHO) where health is "... a state of complete physical, mental and social well-being and not merely the absence of disease or infirmity."2 Although this very well-founded definition has been disregarded for some entirely different priorities of the culture we belong to, its complexity and treatment of man as the union of soul and body united in his personality should be pointed out. We emphasize the person and not the individual because there is indeed a significant difference between them in that the person is - open to others and the community whereas the individual is self-indulged and self-sufficient.

The third, also equally important, side of such reality of ours is a physical education teacher figure. Physical education teachers and their knowledge and commitment to transferring the knowledge OF physical exercise and knowledge FOR physical exercise have strong impact on the attitudes of their (former) students to physical activity and physical exercise later in their life. This knowledge, both practical and theoretical, on the importance and value of physical exercise should remain an eternal value.

Here, and within a theoretical framework as well, is is very important to provide students with clear definitions of concepts, specifically, of physical activity and physical exercise.

\section{Terminology (un)ambiguities}

Nomen est omen, an old Latin phrase, reminds and advises to be wise and cautious when dealing with words and professional terminology in particular that is, they should be used very carefully. This is pointed out because the use of syntagmas - physical activity and physical exercise - as synonyms in professional practice and terminology has become a common practice.

Semantically vague, taken for granted and incorrect use of these terms as synonyms can result in very difficult and distorted conclusions, particularly in the high-level research. Therefore, certain differences between these terms and their conceptual frameworks because of which they cannot be considered synonyms should be indicated.

"Physical exercise is any move or movement one makes with a purpose of improving their psychophysical and motor skills characterized by the degree and

\footnotetext{
${ }^{2}$ https://www.who.int/about/who-we-are/frequently-asked-questions
} 
intensity."3 At the same time, however, physical exercise is the most beneficial nutrient a human being may need.

"Physical activity is also a move or movement made with a purpose which is not necessarily physical exercise. This is commonly an activity aimed at doing everyday tasks: reaching, fetching, throwing, jumping over, going to..., etc." 4

From these indications, it can be concluded that the purpose of a body move or movement dictates whether we talk about a physical exercise (exercising) or a physical activity. If (our) purpose is to complete a working or everyday need, then the moves or movements - that is, physical activity is not a physical exercise or exercising. However, if the purpose of moves or movements is to improve psychophysical and motor skills, then we can consider the given physical activity as physical exercising.

Of course, it happens that these purposes are combined into a single common purpose. For example, working in the garden, walking or riding a bicycle can serve two purposes at the same time: to do a work and to improve one's pshychophysical and motor skills.

Accordingly, it can be concluded that it is very important to use the syntagmas in question carefully in semantic terms. This is similar to two physical measures weight and mass. Although the terms: weight and mass are often interchangeably used in everyday speech, they are two totally different concepts in physics. And they are not used as synonyms in physics whatsoever. Moreover, if they were used as synonyms in physics, it would not only be a sign of ignorance misunderstanding of their meaning but can also lead to a confusion and a lack of reason for any further work and research.

\section{METHOD}

In order to use specific data on physical activity and physical exercise to highlight the importance of physical education in schools, which is the objective of this paper, the results obtained from the study: Eurobarometer - Physical Activity of Vojvodina Citizens as a part of European integration (Research - 2017; published in 2018) are presented. Survey research (survey items were created in compliance with Eurobarometer methodology - for the purpose of comparison) included a sample size of 1025 respondents, male and female, from 112 cities/towns in the AP of Vojvodina, Serbia.

\footnotetext{
3 Zoran Milošević, Nenad Živanović, The Theory of Physical Culture, Faculty of Sport and Physical Education, Novi Sad, 2020, p. 47.

4 Ibid.
} 


\section{RESULTS AND DISCUSSION}

General information on the sample shown in Table 1 indicates that the sample is well balanced and representative of the population and that the obtained results can be used in furhter analyses of physical activity and physical exercise of the AP Vojvodina citizens. In addition, the results can be compared to the results of the study of physical activity and physical exercise of the European Union citizens. This is another good characteristic of the research in question.

Table 1. The sample, characteristics (1025 respondents)

\begin{tabular}{|l|l|}
\hline Gender & $\mathbf{\%}$ \\
\hline Men & 48 \\
\hline Women & 52 \\
\hline Total & $\mathbf{1 0 0}$ \\
\hline
\end{tabular}

\begin{tabular}{|l|l|}
\hline Age & $\mathbf{\%}$ \\
\hline $15-24$ & 19 \\
\hline $25-39$ & 21 \\
\hline $40-54$ & 25 \\
\hline $55+$ & 35 \\
\hline Total & $\mathbf{1 0 0}$ \\
\hline
\end{tabular}

\begin{tabular}{|l|l|}
\hline Subjective urbanisation & $\mathbf{\%}$ \\
\hline Rural village & 22 \\
\hline Small/mid size town & 27 \\
\hline Large town & 51 \\
\hline Total & $\mathbf{1 0 0}$ \\
\hline
\end{tabular}

Results obtained from the research in the AP Vojvodina, Serbia, and the European Union are compared in Tables 2, 3 and 4. The results show that more than a half of the citizens are inactive, which only provides evidence for the widespread "sedentary" lifestyle in the studied area. Furthermore, it is also interesting that improving health is the most common reason for engaging in physical activity and physical exercise. This brings hope that with this motivation together with having fun, physical exercise and physical activity directed to physical exercising can be considered as options of fighting adverse effects of our prevailing sedentary lifestyle. 
Table 2. Frequency of engagement in exercising and playing sport (sport recreation)

\begin{tabular}{|l|l|l|}
\hline & AP Vojvodina, Serbia & EU \\
\hline Regularly & $9 \%$ & $7 \%$ \\
\hline With some regularity & $29 \%$ & $23 \%$ \\
\hline Seldom & $27 \%$ & $14 \%$ \\
\hline Never & $35 \%$ & $46 \%$ \\
\hline
\end{tabular}

Table 3. Frequency of engagement in other physical activities (cycling, walking, dancing, gardening)

\begin{tabular}{|l|l|l|}
\hline & AP Vojvodina, Serbia & EU \\
\hline Regularly & $24 \%$ & $14 \%$ \\
\hline With some regularity & $42 \%$ & $30 \%$ \\
\hline Seldom & $23 \%$ & $21 \%$ \\
\hline Never & $10 \%$ & $35 \%$ \\
\hline
\end{tabular}

Table 4. Motivators

\begin{tabular}{|l|l|l|}
\hline & AP Vojvodina, Serbia & EU \\
\hline To control your weight & $27 \%$ & $23 \%$ \\
\hline To improve fitness & $42 \%$ & $47 \%$ \\
\hline To relax & $38 \%$ & $38 \%$ \\
\hline To have fun & $18 \%$ & $30 \%$ \\
\hline To improve your health & $54 \%$ & $73 \%$ \\
\hline
\end{tabular}

\section{Physical exercise as a beneficial nutrient}

It has already been pointed out that physical exercise is (also) a beneficial nutrient needed by human beings. This is an undeniable fact derived from the acknowledged reality that man is - the union of body and soul, and that physical exercise is the food needed equally by the body and the soul.

Therefore, the knowledge OF physical exercise and the knowledge FOR physical exericse offered through physical education classes are important at the time of complete domination of "sedentary" lifestyle - with a tendency of being transformed into a "couch potato" lifestyle. This is not only a vision and a reminder of ancient Rome, which improved "couch potato" lifestyle through its voyeurism to perfection, but undeniable and threatening truth implied by the results of the study. The results show that more than a half of the citizens are physically inactive. Consequently, only the knowledge acquired in physical 
education classes can help us prevent increasing physical inactivity of European citizens which is usually followed by intelectual inactivity.

When health concerns and a wish to have fun and relax are additional motivations to drive and guide people to physical exercise, they should be used for the purpose. They can help bring physical exercise closer to people and demonstrate that it is a beneficial nutrient. The nutrient everyone needs.

Physical exercising and physical activity oriented toward physical exercising involve not only the time (the degree) and efforts (intensity) consumed. It is also emotionally experienced, as something pleasant or unpleasant, thus this aspect should also be taken into account. Being of indicative and emotional nature, one of the principal motivations guiding people to physical exercise is the very feeling generated by physical exercising that encourages them to break away from the hedonistic offer of "sedentary" lifestyle, stand up from the chair and start moving. A transformation from an inert condition, (also) motivated by pleasant physical exercise, is an immeasurable value of physical exercise and any physical activity oriented toward physical exercising. Consequently, as with any other nutrient, one should be careful when selecting it, taking into account preferences and wishes of each individual. Particular care should be taken about a variety of nutrients and physical exercises with young children. Subsequently, everyone will be able to choose from a variety of nutrients and physical exercises those that are most pleasing and suitable for their age.

An old Middle Ages wise saying suggests: the dose makes the poison. This means that one should be moderate in all things and also in physical exercise and any physical activity oriented toward physical exercising.

Health as the principal motivation driving and guiding people to physical exercising reminds us always to remember this Middle Ages saying.

Value of health should serve as a measure of knowledge offered by physical education.

\section{CONCLUSION}

The method applied in the anthropological research administered in the AP of Vojvodina, Serbian northern province, is in compliance with the method of Eurobarometer, which enables comparison of the obtained results. Analyzed results indicate a decreasing number of people engaged in regular physical exercise both in Serbia and Europe.

This observation is in alignment with the concept of the sedentary society, which is especially a characteristic of Western culture. This inevitably results in "active" hypokinesis, which is underlying many of concerning modifications and health problems. 
Physical exercise, and physical activity oriented to physical exercising, is also the specific and beneficial nutrient needed by everyone. At the same time, physical exercise is the only opportunity - at the time of general technicism - to protect ourselves from intelectual inactivity (too). Time spent in physical exercising is time when we free ourselves from modern technological novelties that drive us away from our selves, the need which is to be even more noticeable in the near future.

Therefore, we highlight the importance of physical education which through its body of knowledge of how and why exercise can help build awareness of the need of physical exercising as well as opportunities to perceive any physical activity as physical exercise..

The main reason to engage in physical exercise is to improve health. And this means health which refers not merely to the absence of disease but also physical, mental and social well-being of ourselves and the society we live in. This motivation together with the motivation of having fun, which reflects another important aspect for any man, and the knowledge acquired at school can encourage people to transform and use any physical activity as physical exercise. And that regularly.

Theoretical and practical knowledge acquired at school provides understanding of the concept of physical exercising and approach to it as to "healthy food" around us and within ourselves. A good physical education teacher will use his or her example and love to plant seeds of required knowledge $\mathbf{O F}$ and knowledge FOR physical exercise into their students. This knowledge can help students abandon the sedentary society and turn to themselves - both at present, and later when they grow up.

School physical education classes and a good teacher are irreplaceable in the intensifying struggle against physical and intellectual inactivity.

\section{REFERENCE LIST}

1. Djordjic Visnja at al.: EUROBAROMETER - Physical Activityof Vojvodina Citizens in the Context of EU Integration, Faculty of Sport and Physical Education, Novi Sad, 2020.

2. Ivashchenko, Sergii: Physical education and state strategic human resources (Hygienic aspects of military-patriotic education for young people by means of physical culture).

Bratislava: Federation Internationale d'education Physique (FIEP), 2017.

3. Ivashchenko, Sergii: Historical preconditions of the origin of self-olympic direction of physical culture in Ukraine Physical education and sport through the centuries 6(2). p. 24-32. 2019.

4. Ivashchenko, Sergii: Innovations in physical education in high schools of Ukraine. Bratislava: Slovak Scientific Society, 2020.

5. https://www.who.int/about/who-we-are/frequently-asked-questions

6. Живановић Ненад и др.: Теорија физичке културе, Паноптикум, Ниш, 2010. 
7. Милошевић Зоран, Ненад Живановић: Теорија физичке културе, Факултет спорта и физичког васпитања, Нови Сад, 2020.

\title{
ФИЗИЧКО ВАСПИТАҢЕ И ЗДРАВ ЖИВОТ
}

\section{САЖЕТАК}

Физичко васпитање, као једно од подручја физичке културе, коју можемо да дефинишемо као: човекову делатност, која као део опште културе, знањима О физичком вежбању и знањима ЗА физичко вежбање унутар својих подручја (физичког васпитања, спорта и физичке рекреације), омогућава трансформацију личности од стварног у могуће, представља веома важну образовну карику. Нарочито је то важно у времену које се карактерише убрзаник технолошким напретком и техницизмом који човека све брже уводи у виртуелну стварност. Због тога истичемо да физичко васпитање знањима 0 и ЗА физичко вежбање, код младих људи гради основу за здрав, активан и дуг живот. То је могуће јер физичко васпитање, ослоњено на Теорију теоантропоцентризма, физичку вежбу види као благотворну храну неопходну човеку. То происходи из односа према човеку као личности, а не индивидуи.

Све присутнија виртуелна стварност, у потпуном је сагласју са седећом културом, све доминантнијој не само у западној цивилизацији. То несумњиво доводи до „активне“ хипокинезије која је у основи многих забрињавајућих промена и здравствених проблема.

Антрополошка истраживања која су обављена у Србији и АП Војводини, потврдила су да је све мањи број људи који се редовно баве физичким вежбањем. Због тога и указујемо на значај физичког васпитања које знањима о томе како и зашто вежбати, изграђује свест о потреби физичког вежбања, као и могућности да се свака физича активност сагледа и као физичко вежбање.

\section{ФИЗИЧЕСКОЕ ВОСПИТАНИЕ И ЗДОРОВЫЙ ОБРАЗ ЖИЗНИ}

\begin{abstract}
АННОТАЦИЯ
Физическая культура, как часть общей культуры, может быть определена как деятельность человека, которая через свои знания О физических упражнениях и ДЛЯ физических упражнений в своих областях (физическое воспитание, спорт и физическая рекреация) позволяет трансформировать личность из реальной в возможную. Физическое воспитание, как одно из направлений физической культуры, является очень важным образовательным звеном. Это особенно важно в эпоху, характеризующуюся
\end{abstract}


быстрым технологическим прогрессом и техничностью, которая быстро вводит людей в виртуальную реальность. Поэтому подчеркивается, что физическое воспитание, с его знаниями О физических упражнениях и ДЛЯ них, создает основу для здоровой, активной и долгой жизни молодых людей. Это возможно благодаря тому, что физическое воспитание, основанное на Теории теоантропоцентризма, рассматривает физические упражнения как полезную деятельность организма, необходимую человеку и вытекающую из отношения к человеку как к личности.

Современная виртуальная реальность находится в полной гармонии с культурой, все более доминирующей не только в западной цивилизации. Это, несомненно, приводит к "активной" гипокинезии, причине многих тревожных изменений и проблем со здоровьем.

Антропологические исследования, проведенные в Сербии и Воеводине, подтвердили, что число людей, регулярно занимающихся физическими упражнениями, сокращается. Именно поэтому указывается на важность физического воспитания, которое, позволяет людям, обладая знаниями о том, как и зачем заниматься физическими упражнениями, формирует осознание необходимости физических упражнений, а также возможности рассматривать каждую физическую активность как физическое упражнение.

Ключевые слова: теоантропоцентризм, физические упражнения, физическая активность. 